\title{
Evaluasi Pelaksanaan Program Character Building Training di Universitas Islam Negeri Alauddin Makassar
}

\author{
Sitti Mania \\ Hasaruddin \\ Universitas Islam Negeri Alauddin Makassar \\ sitti.mania@uin-alauddin.ac.id
}

\begin{abstract}
This research is aimed to: 1) find out the objective condition of supporting elements of Character Building Training Program in State Islamic University of Alauddin Makassar at the antecedent phase, 2) look over the efectivity of the program implementation at the transaction phase, and 3) identify the character of students as the outcome of CBT Program. This formative evaluation research applies qualitative research particulary countenance stake. The data are collected by observation, questionnaire, interview, and documentation. The data are analyzed by domain analysis technique, tacsonomy, and componential technique, based on evaluation phase and applied together with data collecting. This research points out that antecedents phase is on the high category and transaction and outcomes phase are on moderat category.
\end{abstract}

Keywords: Countenance Stake Model, CBT, UIN Alauddin Makassar

Abstrak. Penelitian ini bertujuan untuk mengetahui: 1) kondisi obyektif komponen pendukung program character building training di UIN Alauddin Makassar pada tahapan antecedents, 2) efektivitas pelaksanaan kegiatan program pada tahapan transactions, dan 3) bentukan karakter mahasiswa sebagai hasil (outcomes) dari program CBT. Penelitian evaluasi formatif dengan pendekatan kualitatif ini menggunakan model countenance stake. Pengumpulan data dilakukan melalui observasi, kuesioner, wawancara, dan dokumentasi. Data dianalisis dengan menggunakan teknik analisis domain, taksonomi, dan komponensial berdasarkan tahapan evaluasi dan dilakukan bersamaan dengan pengumpulan data. Hasil penelitian menunjukkan bahwa tahapan antecedents berada pada kategori tinggi, tahapan transaction dan tahapan outcomes berada pada kategori moderat.

Kata Kunci: Model Countenance Stake, CBT, UIN Alauddin Makassar

\section{Pendahuluan}

Dalam undang-undang No. 20 tahun 2003 pasal 3 tentang Sistem Pendidikan Nasional dijelaskan bahwa pendidikan nasional berfungsi mengembangkan kemampuan dan membentuk karakter serta peradaban bangsa yang bermartabat dalam rangka mencerdaskan kehidupan bangsa, bertujuan

ISLAMIC COUNSELING : Jurnal Bimbingan dan Konseling Islam vol. 2, no. 1, 2018 | p ISSN 2580-3638; e ISSN 2580-3646

http://journal.staincurup.ac.id/index.php/JBK 
untuk mengembangkan potensi peserta didik agar menjadi manusia yang beriman dan bertaqwa kepada Tuhan yang maha esa, berakhlak mulia, sehat, berilmu, cakap, kreatif, mandiri dan menjadi warga negara yang demokratis serta bertanggung jawab.

Berbagai upaya telah dilakukan oleh pemerintah dalam membentuk peserta didik menjadi manusia yang berkarakter. Presiden RI pertama, sejatinya telah mencontohkan pentingnya membangun jati diri bangsa melalui konsep national and character building. Hal yang sama dapat dilihat dari pernyataan Ki Hajar Dewantoro bahwa pendidikan adalah daya upaya untuk memajukan bertumbuhnya budi pekerti, pikiran, dan tubuh anak. Bagian-bagian itu tidak boleh dipisahkan agar kita dapat memajukan kesempurnaan hidup anak-anak kita.

Seiring dengan perjalanan waktu, model dan bentuk pendidikan karakter yang dilakukan oleh berbagai lembaga pendidikan formal mulai dari tingkat dasar sampai perguruan tinggi semakin variatif. Berbagai upaya tersebut bertujuan menghasilkan sumber daya manusia Indonesia yang berkarakter, berakhlak mulia, cakap, kreatif serta bertanggungjawab. Gagasan pendidikan karakter muncul sebagai respon atas lemahnya pendidikan dalam membangun manusia Indonesia yang berkarakter.

Upaya lembaga pendidikan formal untuk menyeimbangkan ranah afektif, kognitif, dan psikomotorik/keterampilan peserta didik memang selalu diupayakan, namun faktanya penekanan secara berlebihan terhadap pengembangan sisi kognitif peserta didik berdampak pada tidak berimbangnya perhatian untuk mengembangkan sisi afektif, artinya ranah afektif tidak tersentuh dengan baik dibandingkan dengan kedua ranah yang lain. Akibatnya outputnya memiliki hard skill yang sangat bagus namun bermasalah pada sisi soft skill.

Tidak berimbangnya hard skill dan soft skill kerapkali menyebabkan tindakan anarkis serta konflik sosial yang merambah hampir semua lini kehidupan masyarakat seperti merosotnya nilai moral, penyalahgunaan wewenang oleh para pejabat negara sehingga praktek korupsi bukan lagi sesuatu yang disembunyikan bahkan terkesan dipertontonkan di hampir semua instansi pemerintah kita. Di level mahasiswa contoh merosotnya moral juga sudah sangat sering ditemukan. Sebagai contoh etika berpakaian, tawuran antar mahasiswa, perilaku kasar senior kepada yunior, maraknya plagiasi, hilangnya rasa hormat mahasiswa kepada dosen atau pimpinan fakultas dan universitas secara umum, maraknya penyalahgunaan narkoba, aborsi dan masih banyak lagi contoh kasus yang lain.

Beberapa contoh kasus tersebut memperlihatkan gagalnya dunia pendidikan dalam mencetak manusia yang berkarakter, padahal sejatinya pendidikan merupakan upaya membangun kecerdasan manusia, baik kecerdasan kognitif, afektif maupun psikomotorik/keterampilan. 
Menjawab kenyataan di atas, pemerintah RI kembali menggalakkan pendidikan karakter dengan mencetuskan Kebijakan Nasional Pembangunan Karakter Bangsa tahun 2010-2025. Melalui program ini, pemerintah melibatkan tri pusat pendidikan, yakni keluarga, satuan pendidikan dan masyarakat. Selanjutnya, pendidikan berbasis karakter dijadikan sebagai gerakan nasional mulai dari Pendidikan Anak Usia Dini (PAUD) sampai Perguruan Tinggi termasuk di dalamnya Pendidikan Nonformal dan Informal.

Di Universitas Islam Negeri Alauddin Makassar (selanjutnya disebut UIN Alauddin), pembentukan karakter mahasiswa dilakukan dengan berbagai pendekatan dan strategi, salah satu di antaranya melalui program character building training (CBT).

Berbagai permasalahan yang disebutkan di atas, menjadi sangat penting untuk dikaji dan dievaluasi secara berimbang untuk menentukan tingkat keberhasilan pelaksanaan program CBT di UIN Alauddin Makassar. Penelitian ini menjawab permasalahan, bagaimana kondisi obyektif komponen-komponen yang mendukung terlaksananya program CBT pada tahapan masukan (antecedent) di UIN Alauddin Makassar?, bagaimana efektivitas pelaksanaan kegiatan program CBT pada tahapan proses (transaction)?, dan bagaimana kualitas bentukan karakter mahasiswa sebagai hasil (outcomes) dari pelaksanaan program CBT?

Pembentukan karakter yang dilakukan di perguruan tinggi merupakan program strategis yang diharapkan mampu mengatasi berbagai masalah moral. Dengan demikian evaluasi terhadap keberadaan program CBT sangat penting dilakukan untuk mendapatkan jawaban apakah program berjalan sesuai dengan harapan sekaligus untuk mengetahui sejauh mana tujuan program telah dicapai.

Penelitian ini menggunakan pendekatan kualitatif fenomena logis yang sifatnya studi kasus. Dalam pandangan para ahli, studi kasus bertujuan untuk mengevaluasi fenomena, mendapatkan gambaran detail dari sebuah fenomena, mengembangkan penjelasan-penjelasan dari fenomena yang dipelajari. ${ }^{1}$ Dengan pendekatan kualitatif dapat diperoleh penafsiran mendalam tentang makna dari pelaksanaan CBT yang dilaksanakan di UIN Alauddin Makassar.

Penelitian evaluasi formatif ini menggunakan Stake's contenance model yang dikembangkan oleh Robert E. Stake. Evaluasi model Stake terdiri atas tiga tahapan, yaitu: antecedents, transactions, dan outcomes. Dalam setiap tahapan terdapat dua hal, yakni deskripsi dan keputusan. Teknik pengambilan keputusan pada setiap tahap evaluasi dengan cara melakukan pengukuran pada setiap fokus evaluasi. Pengumpulan data dilakukan dengan menggunakan beberapa teknik,

1 James C. McDavid \& Laura R.L.Hawthom, Program Evaluation \& Performance Measurement An Introduction to Practice, (London: SAGE Publications, 2006), h. 196-197. Lihat juga Donal L. Kirkpatrick \& James D. Kirkpatrick, Evaluating Training Programs, (San Francisco: Berrett-Koehler Publishers, Inc, 2006), lihat juga Huey-Tsyh Chen, Practical Program Evaluation Assessing and Improving Planning, Implementation, and Effectiveness, (London: SAGE Publications, 2005) 
seperti observasi, kuesioner, wawancara, dan analisis dokumen. Untuk memastikan kreadibilitas data yang dikumpulkan digunakan teknik trianggulasi, perpanjangan kehadiran peneliti di lapangan, diskusi teman sejawat, dan pengecekan kecakupan referensi. Data dianalisis dengan menggunakan teknik analisis domain, taksonomi, dan komponensial berdasarkan tahapan-tahapan evaluasi dan dilakukan bersamaan dengan pengumpulan data. Keputusankeputusan yang diambil dijadikan sebagai indikator penilaian kinerja pada setiap tahapan evaluasi dalam tiga kategori yaitu rendah, moderat, dan tinggi.

\section{Pembahasan Utama}

\section{Evaluasi Program}

Melakukan evaluasi pada setiap kegiatan atau program merupakan tahapan penting yang tidak bisa diabaikan. Evaluasi merupakan proses menilai sesuatu berdasarkan tujuan yang telah ditetapkan, kemudian menetapkan keputusan atas obyek yang dievaluasi. Evaluasi dalam pandangan Suharsimi Arikunto dan Cepi Safruddin merupakan kegiatan mencari sesuatu yang berharga tentang sesuatu, mencari informasi yang bermanfaat dalam menilai keberadaan suatu program, produksi, prosedur, serta alternatif strategi yang diajukan untuk mencapai tujuan yang sudah ditentukan. ${ }^{2}$

Daniel L. Stufflebeam mendefenisikan evaluasi sebagai process of delineating, obtaining, and providing descriptive and judgmental information about the worth and merit of some object's goals, design, implementation, and impacts in oreder to guide decision making of the involved phenomena. ${ }^{3}$ Gay mengartikan evaluasi is the systematic process of collecting and analyzing data in order to make decision. ${ }^{4}$ Gronlund \& Linn mengartikan evaluasi sebagai "the systematic process of collecting, analyring, and interpreting information to determine the extent to which pupils are achieving instructional objectives.'.5

Kegiatan evaluasi dalam bidang kajian ilmu termasuk dalam dunia pendidikan sangat beragam, salah satu diantaranya adalah evaluasi program. Evaluasi program mengandung arti suatu kegiatan atau proses untuk mengetahui apakah tujuan program sudah dapat terealisasi. Evaluasi program juga dapat dipahami sebagai upaya menyediakan informasi untuk disampaikan kepada pengambil keputusan. Evaluasi program adalah kegiatan yang sistematis dan berkelanjutan yang bertujuan untuk mendapatkan dan menyajikan data, yang kemudian dapat dipergunakan sebagai acuan dalam membuat keputusan,

\footnotetext{
${ }^{2}$ Suharsimi Arikunto dan Cepi Safruddin, Evaluasi Program Pendidikan, Jakarta: Bumi Aksara, 2008) h. 2

${ }^{3}$ Stufflebeam, Daniel L., Antony J. Shinkfield, Systematic Evaluation, a Self International Guide to Theory and Practice, (Michigan, USA: Kluwer-Nijhoff Publishing, 1986) h. 15

4 L.R. Gay, Educational Research, Competencies for Analysis and Application, (Florida International University, 1981), h. 30

${ }^{5}$ Gronlund, N. E., \& Robert, L. L. Measurement and evaluation in teacbing (New York: Macmillan, 1990)
} 
menyusun kebijakan ataupun menyusun program selanjutnya. Data yang dimaksud adalah data berupa pelaksanaan program, dampak yang ditimbulkan, pemanfaatn hasil evaluasi yang difokuskan untuk program itu sendiri.

Senada dengan beberapa pendapat di atas, Mugiadi dalam Djudju Sudjana menyatakan bahwa evaluasi program adalah upaya pengumpulan informasi mengenai suatu program, kegiatan, atau proyek. Informasi tersebut berguna bagi pengambilan keputusan, antara lain memperbaiki program, menyempurnakan kegiatan program lanjutan, menghentikan suatu kegiatan, atau menyebarluaskan gagasan yang mendasari suatu program atau kegiatan. Informasi yang dikumpulkan harus memenuhi persyaratan ilmiah, praktis, tepat guna dan sesuai dengan nilai yang mendasari dalam setiap pengambilan keputusan. ${ }^{6}$

Evaluasi program dilakukan dengan tujuan: a) memberi masukan bagi perencanaan program, b) menyajikan masukan bagi pengambil keputusan yang berkaitan dengan tindak lanjut, perluasan atau penghentian program, c) memberi masukan bagi pengambil keputusan tentang modifikasi atau perbaikan program, d) memberi masukan terkait dengan faktor faktor pendukung dan penghambat program, e) memberi masukan terkait kegiatan motivasi dan pembinaan bagi penyelenggara, pengelola, dan pelaksana program, dan $\mathrm{f}$ ) menyediakan data tentang landasan keilmuan bagi evaluasi program pendidikan luar sekolah. ${ }^{7}$

Berangkat dari pernyataan di atas, maka dapat dikatakan bahwa dengan melakukan evaluasi terhadap sebuah program tertentu akan didapatkan lima jenis informasi dasar, yakni apakah program layak dilanjutkan, komponen dari program yang paling berhasil, komponen program yang paling efektif, berbagai ciri dasar sasaran program pendidikan sehingga para pengambil keputusan dapat menentukan individu, kelompok atau komunitas mana yang paling merasakan dampak dari layanan program, serta metode-metode baru yang berfungsi memecahkan berbagai persoalan yang berkaitan dengan evaluasi program.

Pernyataan di atas dikuatkan oleh Suharsimi Arikunto dan Cepi Safruddin bahwa terdapat empat kemungkinan yang dapat dilakukan berdasarkan hasil evaluasi pelaksanaan program, yaitu: a) menghentikan program, karena dipandang bahwa program tersebut tidak ada manfaatnya, atau tidak dapat terlaksana sebagaimana diharapkan, b) merevisi program, karena ada bagian-bagian yang kurang sesuai dengan harapan, c) melanjutkan program, karena pelaksanaan program menunjukkan bahwa segala sesuatu sudah berjalan sesuai dengan harapan dan memberikan hasil yang bermanfaat, dan d) menyebarluaskan program, dalam artian melaksanakan program di tempat-

${ }^{6}$ Djudju Sudjana, Evaluasi Program Pendidikan Luar Sekolah. (Bandung: PT Remaja Rosdakarya, 2006), h. 21.

7 Ibid., h. 48. 
tempat lain atau mengulangi lagi program tersebut di lain waktu, karena program tersebut berhasil dengan baik. ${ }^{8}$

Ada banyak model dan pendekatan evaluasi yang dapat dipergunakan dalam mengevaluasi program, penelitian ini mengacu pada model yang ditawarkan oleh Stake, yang kemudian dikenal dengan model countenance. Dalam melakukan evaluasi terhadap sebuah program, Stake menekankan dua dasar kegiatan, yaitu description dan judgement dan membedakan tiga tahap dalam evaluasi program pelatihan, yaitu antecedent (context), transaction (process) dan outcomes. Artinya, dalam setiap tahap, evaluator harus mampu mengidentifikasi tiga hal tadi yang diartikan sebagai hasil.

Dalam pandangan Stake, ketika menilai suatu program, berarti kita melakukan perbandingan yang relatif antara satu program dengan program yang lain, atau melakukan perbandingan absolut, artinya membandingkan suatu program dengan standar tertentu. Dalam pandangan Stake, description berbeda dengan judgement, dalam model ini antecedent, transaction, dan outcomes data dibandingkan dengan maksud untuk menentukan apakah terdapat perbedaan antara tujuan dengan keadaan yang sebenarnya dan juga membandingkannya dengan standar yang absolut untuk menilai manfaat program. ${ }^{9}$

\section{Pembentukan Karakter di UIN Alauddin Makassar}

Dunia pendidikan termasuk perguruan tinggi memiliki peran dan tanggung jawab yang sangat besar untuk membawa perubahan dalam diri pembelajar, masyarakat, dan lingkungan sosial. Perubahan yang dimaksud tidak terbatas pada perubahan tataran kognitif dan psikomotorik/keterampilan saja, namun juga untuk tataran afektif pembelajar. Banyak kajian yang mengulas tentang penekanan secara berlebih pada pembentukan ranah kognitif pembelajar yang kemudian berdampak pada tidak berimbangnya perhatian dan dukungan terhadap pembentukan ranah afektif.

Membentuk ranah afektif pembelajar merupakan suatu keniscayaan, karena kesuksesan seseorang lebih banyak dipengaruhi oleh soft skill. Banyak hasil penelitian yang mengungkap bahwa kontribusi hard skill dalam kesuksesan seseorang hanya sekitar $20 \%$, selebihnya $80 \%$ ditentukan oleh soft skill. Fakta lain menunjukkan bahwa perhatian dunia pendidikan yang berlebih pada ranah kognitif menyebabkan pembelajar, termasuk di dalamnya mahasiswa, hanya cerdas secara akademik namun tidak peka terhadap persoalan sekitar.

Salah satu upaya yang bisa memperbaiki kondisi tersebut adalah dengan membangun karakter pembelajar. Kata karakter berasal dari bahasa Yunani charassein, yang mengandung arti to engrave, berarti mengukir, melukis atau menggambar, seperti orang yang melukis kertas atau memahat batu. Istilah

8 Suharsimi Arikunto \& Cepi Safruddin Abdul Jabbar, Evaluasi Program Pendidikan, (Jakarta: Bumi Aksara, 2009), h. 22

${ }_{9}^{9}$ Farida Yusuf Tayibnapis, Evaluasi Program (Jakarta: Rineka Cipta, 2000), h. 22 
karakter juga dimaknai dengan to mark yang mengandung arti menandai. Istilah yang kedua ini lebih fokus pada tindakan atau tingkah laku. Berangkat dari pengertian bahasa tersebut, Kuppermen kemudian mendefenisikan karakter sebagai instrumen for making and graving, impress, stamp, distinctive mark, distinctive nature. ${ }^{10}$ Dalam pandangan Prayitno dan Bellferik Manulang, karakter adalah sifat pribadi yang relatif stabil pada diri individu yang menjadi landasan bagi penampilan perilaku dalam standar nilai dan norma yang tinggi. ${ }^{11}$ Dengan demikian dapat dikatakan bahwa karakter menjadi ciri khas bagi seseorang yang menjadikannya berbeda dengan orang lain serta mengakar pada kepribadian seseorang tersebut. Ciri khas ini juga akan menjadi pendorong seseorang dalam bertindak, bersikap, dan merespon sesuatu.

Dalam pandangan Wynne karakter mengandung dua pengertian; pertama, menunjukkan bagaimana seseorang bertingkah laku. Apabila seseorang berperilaku tidak jujur, kejam dan rakus, berarti orang tersebut memanifestasikan perilaku buruk. Sebaliknya, apabila seseorang berperilaku jujur, suka menolong, tentulah orang tersebut memanifestasikan karakter mulia. Kedua, istilah karakter erat kaitannya dengan "personality", seseorang baru bisa disebut orang yang berkarakter jika tingkah lakunya sesuai kaidah moral.

Dewasa ini, pada umumnya para pakar pendidikan sepakat tentang pentingnya pendidikan karakter pada pendidikan formal, sehingga menjadi isu penting dalam dunia pendidikan termasuk di perguruan tinggi. Pendidikan karakter merupakan upaya yang dirancang dan dilaksanakan secara sistematis untuk membantu pembelajar memahami nilai-nilai yang berhubungan dengan diri sendiri, sesama, Tuhan, dan lingkungan yang terjewantahkan dalam sikap, perkataan, dan perbuatan berdasarkan norma-norma agama, budaya, dan adat istiadat.

Marvin W. Berkowitz, dalam Nampar Ranaka, memaknai pendidikan karakter sebagai pembentukan jiwa setiap peserta didik, karena karakter adalah konstruksi jiwa peserta didik, karena karakter adalah konstruksi psikologis setiap orang. Target pendidikan karakter adalah akumulasi dari berbagai kemajuan psikologis peserta didik berimbas terhadap kapasitas peserta untuk menjadi agensi moralitas, yang secara personal memiliki etika, moralitas dan tanggung jawab yang baik. ${ }^{12}$

Koesoema dengan mengutip pendapat Foerster mengemukakan empat ciri dasar dalam pendidikan karakter. Keempat ciri tersebut adalah sebagai berikut:

\footnotetext{
${ }^{10}$ Kupperman, Character, (New York: Oxford University Press, 1990), h. 3

${ }_{11}$ Prayitno dan Bellferik Manulang, Pendidikan Karakter dalam Membangun Bangsa (Cet. I, Medan: Pascasarjana Universitas Negeri Medan, 2010), h. 38.

12 Nampar Ranaka, dalam Alwan Suban, dkk. (ed.) Profile Character Building Program (Makassar: Alauddin University Press, 2012), h. 14.
} 
1. Keteraturan interior. Setiap tindakan diukur berdasarkan hierarki nilai, nilai kemudian menjadi pedoman normatif setiap tindakan.

2. Koherensi yang memberi keberanian, membuat seseorang teguh pada prinsip, tidak mudah terombang-ambing pada situasi baru atau takut resiko. Koherensi merupakan dasar yang membangun rasa percaya satu sama lain. Tidak adanya koherensi meruntuhkan kredibilitas seseorang.

3. Otonomi. Seseorang menginternalisasikan aturan dari luar sampai menjadi nilai-nilai bagi pribadi. Hal ini dapat dilihat lewat penilaian atas keputusan pribadi, tanpa terpengaruh atau desakan pihak lain.

4. Keteguhan dan kesetiaan. Keteguhan merupakan daya tahan seseorang guna mengingini apa yang dipandang baik dan kesetiaan merupakan dasar bagi penghormatan atas komiten yang dipilih. ${ }^{13}$

Mengapa pendidikan karakter penting di perguruan tinggi? Alasan utamanya adalah perguruan tinggi dengan tugas utamanya menyelenggarakan pendidikan dan mengembangkan ilmu, pengetahuan, teknologi, serta seni, sudah semestinya juga membentuk karakter, kepribadian, kemandirian serta kecerdasan sosial mahasiswa. Hal ini menjadi sangat penting mengingat mahasiswa merupakan ujung tombak penciptaan peradaban bangsa karena itu mahasiswa harus memiliki karakter yang tangguh, mahasiswa sebagai dinamisator pembangunan harus memiliki daya saing tinggi. Suatu bangsa akan maju jika generasi yang menggantikan lebih baik dari generasi yang diganti. Oleh karena itu, mahasiswa sebagai agen perubahan harus dibekali dengan karakter baik. Kampus merupakan miniatur bangsa, kampus sebagai tempat mahasiswa belajar merupakan salah satu wadah yang mencerminkan kondisi bangsa ke depan, jika tatanan kehidupan kampus sudah baik dan civitas akademika di dalamnya termasuk mahasiswa sudah baik, maka dapat diramalkan kehidupan bangsa ke depan juga akan baik.

Di sisi lain, jika kita melihat dari sudut pandang psikologi perkembangan bahwa manusia pada usia 15 sampai dengan 20 tahun berada pada periode pembentukan watak dan pendidikan agama. Pada masa ini, manusia harus belajar mempertahankan diri dari hal-hal negatif, dan dalam hal ini dibutuhkan dukungan dari lembaga pendidikan formal. Pernyataan ini diperkuat dengan pernyataan Sigmund Freud bahwa masa untuk membentuk kepribadian seseorang masa remaja atau tingkat masa sekolah menengah atas dan menjadi mahasiswa adalah masa pembentukan kepribadian seseorang. ${ }^{14}$

Hal yang sama dikemukakan oleh J.J. Rousseau dan Montessori bahwa godaan-godaan ke arah negatif mulai menyerang dan menjangkiti seseorang saat menginjak usia 18 tahun, karena di usia tersebut seseorang masih mencari jati

13 Doni Koesoema, Pendidikan Karakter (Fakultas Ilmu Pendidikan Universitas Kepausan Salesian, 2010)

14 Sumadi Suryabrata, Psikologi Pendidikan Jakarta: PT. RajawaliGrafindo Persada, 2011), h. 187. 
dirinya. Jika lingkungan tempat mereka lingkungan yang baik, maka serangan dan godaan ke arah negatif dapat dihindari, namun jika sebaliknya, maka yang akan terbentuk adalah perilaku tidak terpuji. Oleh karena itu, mengingat mahasiswa berada pada masa ini, maka pembentukan watak dan penanaman nilai-nilai agama seharusnya mengambil porsi lebih banyak.

Pendidikan berbasis karakter merupakan sebuah solusi atas berbagai masalah yang dikemukakan di atas. Pendidikan karakter berbasis agama dan budaya diharapkan menjadi sebuah inovasi untuk mengembalikan ruh pendidikan yang selama ini mengalami distorsi dan menciptakan insan akademis yang cerdas intelektual, emosional, moral, sosial, kultural, dan spiritual, karena karakter sumber daya manusia yang kuat merupakan modal peradaban bangsa yang unggul. ${ }^{15}$

Pembentukan karakter mahasiswa pada UIN Alauddin Makassar dijewantahkan melalui program CBT. CBT sebagai model pengembangan karakter bagi civitas UIN Alauddin Makassar, khususnya mahasiswa sudah mulai dicanangkan sejak tahun 2010, dan pada tahun 2011 diterbitkan surat keputusan rektor No. Un.06.2/Kp.07.6/145/2011 tentang Tim Persiapan character building training dengan komposisi sebagai berikut: penasehat, pengarah, penanggungjawab, koordinator, ketua, dan anggota. Dari beberapa kali pelaksanaan focus group discussion yang melibatkan aktivis dan funsionaris lembaga kemahasiswaan, dosen, dan pegawai dirumuskan beberapa hal terkait kurikulum dan aktivitas pembelajaran.

Program CBT diperuntukkan bagi seluruh mahasiswa baru UIN Alauddin Makassar tahun akademik yang sementara berjalan. CBT berlangsung selama tiga hari dengan menerapkan model pembelajaran "pondok pesantren mahasiswa" yang berbasis akhlak dan learning society.

\section{Hasil Penelitian dan Pembahasan}

Temuan penelitian dipaparkan secara berurut dengan mengacu pada desain evaluasi yang telah dirancang dengan diawali menyajikan kriteria objektif dari masing-masing tahapan evaluasi dan membandingkannya dengan: a) kondisi objektif dari komponen program CBT pada tahapan antecedents, b) pelaksanaan kegiatan program CBT pada tahapan transactions, dan c) bentukan karakter mahasiswa pada tahapan outcomes.

\section{a. Komponen-komponen yang Mendukung Pelaksanaan Program CBT}

Di bawah ini merupakan kerangka acuan yang melibatkan tiga komponen evaluasi model Stake. Ketiga komponen evaluasi dibahas berdasarkan permasalahan penelitian dan landasan teori serta deskripsi program.

15 Aswin Rauf, Character Building Training (CBT) Model Alternatif Pengembangan Karakter Mahasiswa Berbasis Agama dan Budaya, (Makassar: Alauddin Univeversity Press, 2012), h. 51. 


\section{Komponen antecedents Program CBT}

Komponen antecedents berorientasi pada apa yang dapat dicapai dan apa yang diinginkan oleh sebuah program. Sub-sub komponen yang menjadi fokus dalam mengevaluasi program CBT terdiri atas: a) peserta, b) persyaratan administrasi tim pelatih, c) tim mentor, d) nara sumber, e) sarana dan prasarana, dan, f) kurikulum.

\section{a). Peserta}

Langkah awal dalam pelaksanaan program CBT adalah mendata jumlah mahasiswa yang akan mengikuti kegiatan tersebut. Persentase jumlah mahasiswa baru dengan volume kegiatan dirancang melalui rapat pengelola CBT dengan pimpinan universitas. Hasil rapat selanjutnya disampaikan ke masing-masing fakultas untuk disampaikan ke mahasiswa baru.

Dalam pelaksanaan program, peserta harus siap berada di lokasi pendidikan selama tiga hari, membawa perlengkapan (pakaian, obat-obatan yang diperlukan, perlengkapan ibadah, perlengkapan olahgara, perlengkapan mandi, dan lain-lain yang dianggap perlu), berpenampilan sopan dan sesuai dengan standar kepatutan, harus mengikuti dan bertanggungjawab atas pelanggaran ketentuan atau peraturan pendidikan yang ditetapkan, harus siap diri secara utuh dan total untuk meraih pencerahan, pencerdasan, dan prestasi dan bertanggungjawab atas pengkhitmatan terhadap tiga pilar tersebut, serta harus menempatkan diri sebagai peserta (jangan mengambil penampilan sebagai pelatih, mentor atau unsur lain).

\section{b). Tim Pelatih}

Tim pelatih adalah tim yang sejak awal terlibat dalam proses menggagas pembentukan pendidikan karakter di UIN Alauddin Makassar dan dibentuk oleh rektor UIN Alauddin dimana sebelumnya mereka telah melakukan studi banding ke sejumlah institusi seperti Universitas Paramadina, Universitas Bina Nusantara Jakarta, Yayasan jadi diri bangsa, dan ESQ guna mempelajari berbagai desain yang memiliki kaitan dengan pembinaan karakter mahasiswa. Dengan demikian yang menjadi tim pelatih adalah mereka yang memahami dengan baik pola, pendekatan, model dan strategi pembinaan mahasiswa.

Tim pelatih bertugas melakukan perekrutan mentor melalui training of trainer serta bertugas membuat formulasi pendidikan melalui pemilihan materi serta stakeholder pendidikan yang dilaksanakan untuk memberikan substansi baik secara kualitatif maupun secara kuantitatif pelaksanaan pendidikan. Tim pelatih dikoordinir oleh seorang koordinator pelatih serta didampingi oleh anggota tim pelatih. ${ }^{16}$ Dalam melaksanakan tugasnya, tim pelatih senantiasa melakukan

16 Aswin Rauf, Character Building Training (CBT) Model Alternatif Pengembangan Karakter Mahasiswa Berbasis Agama dan Budaya, (Makassar: Alauddin Univeversity Press, 2012), h. 64 
koordinasi internal dan komunikasi kepada pihak pimpinan UIN alauddin Makassar.

Dalam pelaksanaan program CBT, tim pelatih harus tunduk pada beberapa aturan, antara lain: harus prima selama proses pendidikan, selalu bersahaja dan empati selama proses pendidikan, penampilan sesuai ketentuan, siap untuk menjadi mentor dan nara sumber, serta berwawasan luas dan fleksibel.

\section{c). Tim Mentor}

Mentor atau instruktur merupakan salah satu komponen penting dalam pelaksanaan program CBT, karena keberhasilan pelaksanaan program tergantung pada cara mentor mengelola kelompok yang menjadi tanggung jawabnya. Mentor adalah tim yang direkrut melalui penilaian tertentu dan mewakili seluruh fakultas dan mengikuti pelatihan keinstrukturan. ${ }^{17}$ Mentor dipilih dari unsur dosen oleh tim pelatih melalui seleksi yang sangat ketat. Ada beberapa persyaratan yang harus dipenuhi oleh mentor, seperti dosen tetap UIN Alauddin Makassar, sehat lahir batin, tidak pernah dihukum, utusan dari masing-masing fakultas pada lingkup UIN Alauddin Makassar, dekat dengan mahasiswa, memiliki kemampuan public speaking yang baik, serta bersedia mengikuti training of trainer.

Mentor berfungsi dan berperan membentuk kelompok sekaligus sebagai mentor tiap kelompok, membuka pelatihan tiap sesi, memimpin game, menjelaskan teknik game, membuat papan absen, menyediakan instrumen absen, menyediakan instrumen game, memimpin ibadah memberikan contoh tentang disiplin pendidikan, memastikan ketepatan awal dan akhir setiap sesi, memberikan pengantar sesi materi, menjaga dan mengevaluasi kedisiplinan peserta, mendinamisasi dan menghidupkan suasana secara kreatif dan inovatif, memperkuat citra keunggulan program pengembangan karakter di tengahtengah suasana pendidikan, selalu tampil dengan rapi dan kostum yang etis, memastikan ketersediaan kelengkapan alat atau properti yang dibutuhkan selama pendidikan, berkoordinasi terus menerus dengan tim pelatih, memastikan kesehatan peserta selama pendidikan, melakukan monitor dan pendampingan selama 40 hari pasca pendidikan terhadap alumni pendidikan tiap angkatan dengan mengangkat seorang presiden alumni dan memfasilitasi seluruh gerakan dan prosesn pendidikan baik di dalam kelas maupun di luar kelas. $^{18}$

Selama pendidikan berlangsung, tim mentor harus 1) siap berada di lokasi pendidikan, 2) harus siap mendampingi peserta secara disiplin, telaten, dan penuh ketulusan, 3) datang lebih awal dari peserta di tempat pendidikan baik di kelas, di lapangan, maupun di tempat ibadah, 4) memberikan dan

\footnotetext{
17 Ibid.

18 Ibid., h. 65
} 
mengontrol stiker absensi, 5) berpenampilan ramah, bersahaja, dan bersih, 6) membuka dan menutup setiap sesi pendidikan, 7) mempersiapkan manual jadwal pendidikan, 8) mempersiapkan rangkaian acara ibadah, dan 9) konsisten serta komitmen terhadap waktu dan agenda pendidikan. ${ }^{19}$ Tujuan ditetapkannya tata tertib tersebut untuk memberikan quality assurance dalam pelaksanaan kegiatan program CBT.

\section{d). Nara sumber}

Nara sumber dalam sebuah kegiatan pendidikan merupakan salah satu komponen penting, nara sumber dalam program CBT terdiri atas dua kategori yaitu nara sumber tetap dan nara sumber tamu. Nara sumber tetap berasal dari UIN Alauddin Makassar yang berstatus dosen dan merupakan tim pelatih. Nara sumber tamu adalah tim yang dipilih berdasarkan kebutuhan dan dinamika pendidikan yang diundang khusus dan dianggap kompeten dalam bidang materi yang harus disampaikannya.

Nara sumber berfungsi dan berperan untuk memberi penajaman secara mudah dan praktis materi-materi utama yang telah disiapkan secara tertulis oleh tim pengelola program CBT. Tim nara sumber harus memenuhi kriteria yaitu: 1) penampilan menarik, 2) berwawasan luas, 3) memiliki track record yang cukup baik, 4) dikenal relatif populer, 5) dinamis, 6) supel, 7) komunikatif, 8) memiliki kemampuan public speaking yang memadai, 9) berpengalaman, 10) serta mendapat penilaian positif dari kegiatan evaluasi.

\section{e). Sarana dan Prasarana}

Sarana dan prasarana yang dipergunakan dalam kegiatan program CBT adalah fasilitas UIN Alauddin Makassar, terdiri atas masjid kampus, auditorium yang dipergunakan untuk pelaksanaan indoorclass, dan untuk tempat bermalam peserta menggunakan asrama mahasiswa. Untuk kegiatan outdoorclass dilaksanakan di bukit pesona alam desa Bilaya kecamatan Pattalassang kabupaten Gowa.

\section{f). Kurikulum}

Salah satu komponen program CBT yang harus dikelola dengan baik adalah komponen kurikulum. Kurikulum yang dimaksud di sini adalah sejumlah materi yang harus diikuti oleh peserta program dalam rangka pembentukan karakter tertentu yang menjadi target pelaksanaan program. Materi dari program CBT dibagi menjadi beberapa kelompok:

- Materi Dasar, antara lain:

a. Materi keislaman; yang terkait dengan ide-ide: i) induktif-empirical bayani, ii) deduktif rasional burhani, iii) intuitif spiritual irfani, sekitar ruh dan inner capacity, dzikrullah dan tadarrus al-Quran. 
b. Wawasan kebangsaan: Pancasila, UUD 1945, NKRI dan Bhinneka Tunggal Ika.

c. Dasar-dasar philosophy of science (filsafat keilmuan)

d. Ke-Tri dharma PT-an, mencakup: i) mengenal pembelajaran orang dewasa dan kiat sukses belajar di perguruan tinggi, ii) dasar-dasar participatory action research (PAR), iii) dasar-dasar participatory rural appraisal (PRA).

e. Materi Pengembangan, antara lain: i) mahasiswa sebagai sumber insani bangsa, ii) membangun tradisi akademik dan etika keilmuan mahasiswa, iii) mahasiswa dan demokrasi: ikhtiar membangun jejaring sosial politik yang sehat dan bermartabat.

- Materi life skill dan talenta, mencakup: i) menyusun peta hidup dan mengantisipasi masa depan, ii) pengembangan kemampuan bahasa asing dalam bentuk practical meeting club, iii) dasar-dasar leadership, iv) entrepreneurship, v) teknik penulisan karya ilmiah populer dan jurnalistik, vi) art show, dan vii) olah raga dalam berbagai bentuk, viii) pelaksanaan training sepenuhnya menggunakan metode pembelajaran orang dewasa dalam bentuk in class training dan out class training. In class training meliputi antara lain: ceramah, simulasi, game, jigsaw, problem solving method, brainstorming, focus group discussion dan telaah kasus. Out class training meliputi antara lain: visiting study (institusi terkait: masjid, parlemen, birokrasi, pers, rumah kesenian, sekolah alternatif, LBH, lembaga kajian, ormas, partai politik, lembaga kursus bahasa asing, dan sebagainya), kunjungan lapang: akivitas kreatif mahasiswa, advokasi NGO, legal standing, hearing DPRD, dan sebagainya), membuat laporan tertulis hasil kunjungan lapangan atau visiting study untuk kemudian didiskusikan dalam kelas. ${ }^{20}$

Semua materi di atas dikemas dalam tema relasi diri dengan Tuhan, relasi diri dengan diri, relasi diri dengan orang lain, relasi diri dengan orang tua, dan relasi diri dengan lingkungan.

Berdasarkan standar objektif program CBT pada komponen antecedents yang dikemukakan di atas, dan hasil evaluasi dari data lapangan, maka di bawah ini dipaparkan hasil evaluasi pada masing-masing aspek komponen. Pada aspek peserta, rekrutmen peserta berjalan dengan baik ditandai dengan jumlah peserta yang proporsional dengan daya tampung auditorium dan asrama mahasiswa serta jumlah mentor yang diturunkan setiap angkatan. Peserta juga terdiri atas mahasiswa dari berbagai fakultas dan jurusan yang berbeda.

Aspek tim pelatih, tim mentor serta nara sumber pada umumnya juga sudah berjalan sesuai dengan standar objektif yang terdapat dalam pedoman pelaksanaan CBT. Dalam hal perekrutan, sudah memenuhi persyaratan administrasi yang ditetapkan bahkan tidak sedikit dari mereka memiliki

20 Ibid., h. 56 \& 57. Lihat juga Alwan Suban, dkk., Profil Ma'had Al-Jami'ah Character Building Program (CBP), (Makassar: Universitas Islam Negeri (UIN) Alauddin Makassar, 2015), h. $58 \& 59$. 
pengalaman mengelola berbagai lembaga dan menjadi trainer pada berbagai kegiatan pengabdian masyarakat di luar kampus.

Terkait dengan sarana dan prasarana, gedung auditorium, asrama mahasiswa lapangan kampus, lingkungan kampus yang asri, merupakan faktor pendukung terlaksananya kegiatan CBT. Lain halnya dengan masjid, karena daya tampung masjid sangat terbatas, sehingga penggunaannya dalam menunjang kegiatan program CBT menjadi sedikit terkendala. Begitu pula ketika mahasiswa berada di bukit pesona alam sebagai lokasi outdoor, fasilitas yang bersifat tentatif seperti tenda, sarana MCK, lighting, soundsystem terkadang menjadi masalah tersendiri.

Kurikulum yang dirancang sedemikian rupa yang mencakup materi dasar dan materi life skill yang mencakup kiat-kiat pengembangan diri, enterpreunership, kewarganegaraan, pemberantasan korupsi bahkan materi pendidikan pra-nikah dan sejenisnya yang kemudian dikemas menjadi tema relasi diri dengan Tuhan, relasi diri dengan diri, relasi diri dengan orang lain, relasi diri dengan orang tua, serta relasi diri dengan lingkungan menjadikan program CBT memiliki keunggulan tersendiri yang menjadikannya berbeda dengan program pembinaan karakter pada umumnya. Sehingga tidak mengherankan jika perguruan tinggi lain seperti IAIN Kendari dan IAIN Palopo melaksanakan kegiatan pembinaan karakter mahasiswa dengan melibatkan tim pelatih CBT UIN Alauddin Makasar.

\section{b. Komponen Transactions Program CBT}

Komponen transaction adalah komponen yang mengevaluasi proses atau implementasi kegiatan, termasuk mengidentifikasi kesalahan prosedur kegiatan baik tata laksana kejadian maupun dan aktivitas. ${ }^{21}$ Mengingat kompenen transactions mengevaluasi proses, maka komponen ini mengungkap bagaimana pelaksanaan program CBT di UIN Alauddin Makassar.

Kegiatan training dilaksanakan selama tiga hari satu malam dengan menggunakan dua kondisi dan tempat yang berbeda, yakni indoorclass dan outdoorclass.

Kegiatan pada indoorclass diawali dengan pembukaan secara resmi oleh pihak pimpinan universitas dan kemudian dilanjutkan dengan perkenalan. Pada sesi perkenalan, pelatih memperkenalkan pelatih, mentor, selanjutnya perkenalan antar sesama peserta. Kegiatan perkenalan bertujuan untuk menghilangkan suasana formal dan menghadirkan suasana keakraban antar semua unsur yang terkait dengan pelaksanaan training, yang dalam istilah training CBT adalah untuk membangun relasi diri dengan diri serta relasi diri dengan orang lain.

21 Daniel L. Stufflebeam \& Anthony J. Shinkfield, Evaluation Theory, Models, and Applcation. USA: John Willey \& Sons, Inc. 2007 
Kegiatan dilanjutkan dengan membagi peserta ke dalam dua kelompok besar, kelompok laki-laki dan kelompok perempuan. Kelompok besar kemudian dirampingkan dengan membentuk kelompok kecil secara acak yang beranggotakan sebanyak tujuh sampai sepuluh mahasiswa dari berbagai fakultas dan jurusan yang berbeda. Setiap kelompok didampingi oleh seorang mentor. Kegiatan awal dalam kelompok kecil adalah membuat nama kelompok, yel-yel sebagai identitas peserta yang akan tetap disandang sampai selesai pelaksanaan training, di samping itu, yel-yel ditampilkan pada segmen show performance. Kegiatan dilanjutkan dengan menerima materi dan pendalaman materi dan diselingi dengan game edukatif yang semua dikemas dengan pendekatan pembelajaran orang dewasa.

Setelah kegiatan selesai pada indoorclass, kegiatan dilanjutkan di outdoorclass. Penyadaran diri mahasiswa dalam membangun relasi diri dengan alam semesta menjadi alasan utama mengapa kegiatan training dilanjutkan di outdoorclass.

Hal pertama yang dilakukan oleh peserta pada outdoorclass adalah shalat magrib berjamaah. Shalat berjamaah dilakukan di alam bebas, dengan maksud memberikan penyadaran kepada peserta bahwa selain manusia juga ada makhluk lain yang beribadah menurut cara dan sistem yang telah ditetapkan oleh-Nya. Ini merupakan ciri khas kegiatan CBT UIN Alauddin dengan kegiatan lainnya, yakni sarat dengan simbol dan nilai filosofis. Setelah shalat isya, peserta unjuk bakat yang dikemas dengan kegiatan artshow. Artshow dalam bingkai CBT merupakan salah satu basis pendidikan karakter yakni basis budaya. Peserta yang tampil dengan latar belakang budaya yang heterogen menghasilkan sajian unik yang memberikan informasi dan inspirasi bagi peserta lain. Artshow merupakan kegiatan yang bertujuan menghangatkan kondisi training. Sebagai puncak acara kegiatan training adalah saat peserta bangun shalat tahajjud dan mengikuti prosesi muhasabah terhadap sikap dan perilaku mereka sebelum mengikuti training. Dalam pandangan para pelatih dan mentor, tengah malam dijadikan sebagai puncak pelaksanaan training sebab semua energi murni dari alam semesta muncul pada saat tengah malam.

Sebagai kegiatan akhir dari training, setelah shalat subuh, peserta berolahraga bersama, dilanjutkan dengan kegiatan memadatkan cita menjaring masa depan dan resolusi hidup.

Hal menarik dari kegiatan training CBT adalah secara individu peserta diharuskan mengisi lembar kerja setiap selesai menerima materi. Hal tersebut berfungsi sebagai reinforcement penguasaan peserta terhadap materi yang telah diterima, serta berfungsi sebagai pengingat dan motivasi mereka setelah mengikuti training.

Setelah kegiatan indoorclass dan outdoorclass selesai, tahap selanjutnya yang harus dilalui mahasiswa adalah pembinaan lanjutan, salah satu bentuk pembinaan lanjutan adalah mentoring yang berlangsung selama empat puluh 
hari terhitung sejak selesainya masa training. Kegiatan mentoring dilakukan dengan maksud memantau pelaksanaan resolusi mahasiswa.

Untuk kegiatan mentoring, mahasiswa didampingi oleh masing-masing mentor dan dibekali lembar kerja 7. Dalam lembar kerja 7 tersebut mahasiswa menulis resolusi diri dengan disaksikan oleh dua orang temannya dan diketahui oleh mentornya. Resolusi diri harus memuat kebiasaan baru terkait dengan materi yang mereka terima pada saat training dan mereka lakukan pasca training. Kebiasaan baru tersebut mencakup relasi diri dengan Tuhan, relasi diri dengan diri, relasi diri dengan orang tua, relasi diri dengan lingkungan, dan relasi diri dengan orang lain.

Selama pelaksanaan mentoring, mahasiswa diharuskan menemui mentornya sebanyak lima kali yang dibuktikan dengan tanda tangan mentor dan tanggal pelaksanaan mentoring. Pertemuan dengan mentor bertujuan untuk mendiskusikan perkembangan kebiasaan baru mahasiswa yang sudah terbentuk setelah mengikuti training, serta membahas faktor pendukung dan penghambat pelaksanaan resolusi diri. Peran mentor dalam pelaksanaan mentoring sangat vital, karena komitmen mentor untuk selalu memotivasi, mengingatkan dan melakukan komunikasi dengan mahasiswa merupakan kunci utama keberhasilan mentoring. Lulus tidaknya atau layak tidaknya mahasiswa bersangkutan mendapatkan sertifikat lulus sangat tergantung oleh mentor masing-masing. ${ }^{22}$

Berdasarkan standar objektif program CBT pada komponen transactions yang dikemukakan di atas, dan hasil evaluasi dari data lapangan, maka di bawah ini dipaparkan hasil evaluasi pada masing-masing aspek komponen.

Berdasarkan wawancara yang dilakukan kepada beberapa alumni diperoleh informasi bahwa pada aspek penyampaian materi belum sepenuhnya mengejawantahkan model-model yang variatif yang mengacu pada pembelajaran orang dewasa, dan ada beberapa nara sumber yang dalam penyampaian materinya menggunakan bahasa yang sangat sulit dicerna oleh peserta sehingga peserta menjadi mengantuk dan sulit terlibat secara aktif dalam proses pembelajaran.

Kendala lain yang ditemukan pada tahap transactions adalah terkadang bagi mahasiswa tertentu pelaksanaan training beririsan dengan kegiatan perkuliahan oleh dosen eksternal UIN Alauddin atau kegiatan akademik mahasiswa seperti kegiatan praktek. Kendala lain yang ditemukan saat pelaksanaan training adalah keterlibatan sebagian mentor tidak maksimal dikarenakan beririsan dengan kegiatan lain.

Persoalan mentoring menjadi masalah utama yang ditemukan pada tahap transactions. Melalui wawancara dengan beberapa mentor dan beberapa mahasiswa, baik yang sementara menjalani masa mentoring maupun mahasiswa yang pernah mengikuti program CBT serta melalui pengamatan ketika

22 Alwan Suban, dkk., Profil Ma'had Al-Jami'ah Character Building Program (CBP), (Makassar: Universitas Islam Negeri (UIN) Alauddin Makassar, 2015), h. 61 
mahasiswa melakukan mentoring ditemukan fakta bahwa pelaksanaan mentoring belum berjalan sesuai dengan konsep ideal serta belum menyentuh ruh pelaksanaan CBT.

Terdapat beberapa situasi yang menyebabkan mentoring tidak berjalan sesuai dengan harapan, di antaranya:

- Komitmen mentor. Beberapa mentor yang hanya menandatangani lembar resolusi para mahasiswa mentoringnya tanpa melakukan dialog terkait dengan perkembangan resolusi diri yang sudah dibuat oleh peserta pada saat training. Bahkan tidak jarang, lembar resolusi hanya dititip di staf dan kemudian mahasiswa kembali mengambil di staf setelah ditandatangani oleh mentor, sehingga dialog terkait dengan terlaksana tidaknya resolusi mahasiswa tidak pernah terjadi. Praktek lain seperti sekali mengunjungi mentor, mahasiswa mendapat tanda tangan sebanyak lima kali.

- Kapabilitas mentor. Kegiatan mentoring bertujuan untuk memonitoring dan mengevaluasi keterlaksanaan resolusi diri mahasiswa, oleh karena itu dibutuhkan kemampuan komunikasi yang baik dari para mentor untuk menggali lebih dalam kemungkinan-kemungkinan faktor pendukung dan penghambat pelaksanaan resolusi diri serta memberi solusi atas setiap kendala yang dialami oleh mahasiswa. Namun faktanya, banyak mentor yang tidak melakukan hal tersebut dengan baik, dikarenakan tidak memiliki kepekaan terhadap permasalahan mahasiswa serta tidak komunikatif. Dalam kondisi demikian, meskipun antara mentor dan mahasiswa bisa bertemu namun target pelaksanaan mentoring tidak tercapai dengan baik.

- Waktu mentoring. Tim mentor memiliki kegiatan yang sangat banyak di samping harus melakukan mentoring, mahasiswa juga sudah harus kembali ke aktivitas perkuliahan yang sangat padat, sehingga persoalan mencocokkan waktu antara mentor dan mahasiswa menjadi masalah tersendiri akibatnya pelaksanaan mentoring tidak efektif.

- Rasio mentor dan mahasiswa. Dari tahun ke tahun, penerimaan mahasiswa baru di UIN Alauddin Makassar terus memperlihatkan grafik naik, sementara jumlah mentor tidak mengalami penambahan yang signifikan. Akibatnya mentor harus melayani mahasiswa dengan jumlah yang tidak sedikit dari satu angkatan ke angkatan berikutnya.

\section{c. Komponen Outcomes Program CBT}

Komponen outcomes menyasar evaluasi keberhasilan pencapaian tujuan yang telah ditetapkan. ${ }^{23}$ Evaluasi hasil adalah upaya menafsirkan hasil yang telah dicapai dari pelaksanaan sebuah program. Komponen outcomes dalam penelitian ini berusaha melihat bentukan karakter mahasiswa setelah mengikuti training,

${ }^{23}$ Daniel L. Stufflebeam \& Anthony J. Shinkfield, Evaluation Theory, Models, and Applation. USA: John Willey \& Sons, Inc. 2007 
terkait dengan relasi diri dengan Tuhan, relasi diri dengan diri, relasi diri dengan orang lain, dan relasi diri dengan orang tua, serta relasi diri dengan lingkungan.

Dalam pedoman pelaksanaan CBT dikemukakan bahwa CBT UIN Alauddin Makassar sebagai pilot program nasional dalam rangka menumbuhkan, merawat dan mengawal karakter akhlak bangsa di masa depan, setidaknya ada lima kesadaran fundamental yang diharapkan tumbuh dan menopang pembentukan karakter di kalangan mahasiswa, yakni:

- Wawasan theosentris yakni terwujudnya kesadaran diri dalam membangun ketundukan harmoni kepada sang Khalik.

- Wawasan kosmosentris, yakni terwujudnya kesadaran diri dalam memandang kosmik atau jagad semesta sebagai "saudara kosmik" dengan manusia.

- Wawasan antroposentris, yakni kesadaran diri dalam membangun relasi harmoni antar individu maupun antar individu dan komunitas sosial yang lebih luas,

- Wawasan kultur dan kearifan, yakni kesadaran diri untuk menggali dan mengapresiasi tradisi lokal sebagai pilar-pilar penting kebudayaan bangsa, khususnya dalam menata dan merawat wawasan kebangsaan dalam kerangka NKRI,

- Wawasan logosentris, yakni kesadaran diri dalam membangun tradisi pemikiran, wacana intelektual dan iklim keilmuan guna membangun sebuah peradaban yang lebih besar dan lebih bermartabat. ${ }^{24}$

Dengan mencermati isi pedoman pelaksanaan program CBT UIN Alauddin Makassar, maka dapat dipahami bahwa program ini secara umum bertujuan untuk mengawal mahasiswa pada perbaikan pandangan, sikap, dan perilaku baik terhadap Tuhan, diri sendiri, orang lain, orang tua, dan lingkungan.

Relasi diri dengan Tuhan akan menimbulkan kesadaran pada mahasiswa bahwa manusia merupakan makhluk yang tidak lepas dari ikatan hubungan denganNya sehingga dalam kehidupan keseharian, mereka senantiasa merasakan kehadiran Tuhan sehingga akan menjadi alat kontrol dalam bersikap dan bertindak. Relasi diri dengan diri sendiri berarti mengenal kekuatan dan kelemahan baik dari segi fisik, psikis, maupun spiritual sehingga memudahkan pengembangan diri dan potensi positif untuk menjadi orang yang sukses dalam hidup. Relasi diri dengan orang lain akan membangun kesadaran pada mahasiswa bahwa seseorang ada karena ada orang di luar dirinya, manusia sebagai mahkluk sosial yang memiliki ketergantungan yang sangat tinggi pada pihak lain sehingga pada akhirnya mereka akan menyadari bahwa kesuksesan yang diperoleh bukan hanya ditentukan oleh seseorang itu secara individu namun ada keterlibatan orang lain. Relasi diri dengan orang tua akan menyadarkan mahasiswa untuk menghormati orang tua. Relasi diri dengan 
lingkungan akan membangun kesadaran mahasiswa bahwa lingkungan atau alam semesta merupakan bagian dari diri manusia sehingga tindakan mengelolah lingkungan merupakan wujud penghargaan terhadap diri sendiri. Sehingga mahasiswa tidak membuang sampah di sembarang tempat, memarkir kendaraan dengan baik dan sebagainya.

Dari hasil wawancara dengan beberapa tim pelatih dan mentor, peneliti menyimpulkan bahwa dengan menghayati kelima relasi di atas, maka mahasiswa akan menjadi mahasiswa yang berkarakter, mampu menjadi orang baik dan dapat memberi manfaat baik kepada diri sendiri, maupun kepada orang lain dan lingkungan.

Berdasarkan hasil wawancara, angket dan observasi, berikut ini akan dipaparkan dampak positif dari pelaksanaan CBT. Dampak positif dapat dilihat dari kuantitas jamaah di masjid, sebagian besar alumni mengatakan dirinya menjadi lebih dekat dengan-Nya setelah mengikuti CBT, perilaku negatif dapat berubah ke positif, seperti tidak lagi lalai dalam menjalankan shalat lima waktu, berusaha shalat tahajjud, shalat dhuha serta shalat sunat rawatib, kebiasaan merokok dapat dihilangkan setelah mengikuti CBT, lebih disiplin dalam mengikuti perkuliahan dan mengerjakan tugas, dapat mengatur waktu dengan baik, dapat berempati dan menghargai orang lain, dapat lebih merasakan pengorbanan orang tua, serta hal positif lainnya.

Kondisi berbeda dengan fakta di atas masih didapati di lingkungan kampus, seperti mahasiswa membuang sampah sembarang tempat, kantin mahasiswa sangat jorok, merokok bahkan di tempat umum, segelintir mahasiswa masih bersantai di kantin saat sebagian besar mahasiswa sudah shalat berjamaah di masjid, tawuran antar fakultas tertentu dan merusak fasilitas dan aset kampus, memarkir kendaraan tidak pada tempatnya, segelintir mahasiswa bersikap tidak sopan kepada para dosen dan pegawai dan sebagainya.

\section{Kesimpulan}

Berdasarkan uraian hasil penelitian dan pembahasan serta analisis evaluatif terhadap pelaksanaan program CBT pada UIN Alauddin Makassar, maka diperoleh beberapa simpulan sebagai berikut:

Pertama, Kondisi objektif komponen antesedents yang mencakup peserta, tim pelatih, tim mentor, nara sumber, sarana prasarana, serta kurikulum berada pada kategori tinggi. Kedua, Kondisi objektif komponen transaction yang mencakup pelaksanaan kegiatan program berada pada kategori moderat. Ketiga, Kondisi objektif komponen outcomes yang mencakup bentukan karakter positif mahasiswa setelah mengikuti program CBT berada pada kategori moderat. Keempat, Dua dari tiga tahapan berada pada kategori moderat menunjukkan bahwa pelaksanaan program CBT di UIN Alauddin Makassar dianggap berhasil dengan kategori moderat. 
20 | ISLAMIC COUNSELING : Jurnal Bimbingan dan Konseling Islam, vol. 2, no. 1, 2018

\section{Bibliografi}

Arikunto, Suharsimi dan Cepi Safruddin, 2008, Evaluasi Program Pendidikan, Jakarta: Bumi Aksara.

Chen, Huey-Tsyh, 2005, Practical Program Evaluation Assessing and Improving Planning, Implementation, and Effectiveness, London: SAGE Publications.

Daniel L. Stufflebeam \& Anthony J. Shinkfield, 2007, Evaluation Theory, Models, and Applcation. USA: John Willey \& Sons, Inc.

Gay, L.R. Educational Research, Competencies for Analysis and Application, 1981, Florida International University.

Gronlund, N. E., \& Robert, L. L. 1990, Measurement and evaluation in teaching, New York: Macmillan.

Kirkpatrick, Donal L. \& James D. Kirkpatrick, 2006, Evaluating Training Programs, San Francisco: Berrett-Koehler Publishers, Inc.

Kupperman, 1990, Character, New York: Oxford University Press.

Koesoema, Doni, 2010, Pendidikan Karakter, Fakultas Ilmu Pendidikan Universitas Kepausan Salesian.

McDavid, James C. \& Laura R.L.Hawthom, 2006, Program Evaluation \& Performance Measurement An Introduction to Practice, London: SAGE Publications.

Prayitno dan Bellferik Manulang, 2010, Pendidikan Karakter dalam Membangun Bangsa, Cet. I, Medan: Pascasarjana Universitas Negeri Medan.

Rama, Bahaking, 2012, Relasi Diri dengan Lingkungan, Makasar: Alauddin University Press.

Rauf, Aswin, 2012, Character Building Training (CBT) Model Alternatif Pengembangan Karakter Mahasiswa Berbasis Agama dan Budaya, Makassar: Alauddin Univeversity Press.

Suban, Alwan, dkk., 2015, Profil Ma’had Al-Jami'ah Character Building Program $(C B P)$, Makassar: Universitas Islam Negeri (UIN) Alauddin Makassar.

Sudjana, Djudju. Evaluasi Program Pendidikan Luar Sekolah. 2006, Bandung: PT Remaja Rosdakarya.

Suryabrata, Sumadi, 2011, Psikologi Pendidikan, Jakarta: PT. RajawaliGrafindo Persada.

Stufflebeam, Daniel L., Antony J. Shinkfield, 1986, Systematic Evaluation, a Self International Guide to Theory and Practice, Michigan, USA: Kluwer-Nijhoff Publishing.

Tayibnapis, Farida Yusuf. 2000, Evaluasi Program, Jakarta: Rineka Cipta. 